Volume 7 Issue 1, March 2020

Nationally Accredited Journal,

Decree No. B/4130/E5/E5.2.1/2019

\title{
Reconstruction Of Notary Position Authority and Implementation Of Basic Concepts Of Cyber Notary
}

\begin{abstract}
Masrur Ridwan ${ }^{1}$
Abstract. E-notary or cyber notary which has become a necessity as a form of adjustment to the development of the times, although its presence is agreed to be impossible to avoid, but it still leaves a pro-cons opinion. Some support and some refuse. Problems that arise related to the validity of the deed made in the cyber notary work system (cyber notary). However the practice of cyber notary in Indonesia today, it will reduce the strength of proof of authentic deed. The decrease is parallel with the text of Article 5 paragraph (4) of the ITE Law which emphasizes that the electronic deed does not have perfect proof of strength like a deed of qualification. Until now the electronic deed is still regarded as a deed under the hand that is equal in value to documents. But the presence of COVID-19, which since March 11, 2020, was determined by WHO as a pandemic, like it or not, forced us to think or review the implementation of the basic concepts of cyber notary. Posts that use the statute approach and the concept are expected to be able to encourage related parties to review the authority of the Notary Position in authorizing the certification of transactions conducted electronically.

Keywords: Reconstruction; Notary Authority; Implementation; Basic Concepts of Cyber Notary
\end{abstract}

\section{Introduction}

The use of telecommunications media and information technology makes it easier for the public to process business transactions. The presence of increasingly sophisticated internet networks, in addition to making the world more without barriers, also makes it easier for human beings to carry out all their activities. This development can be seen from the existence of electronic agreements or contracts, online buying and selling (in networks) and others. Moreover, the presence of online services is also utilized and developed for public services, such as electronic contracts for the procurement of goods / services in government projects, identity card services (KTP), implementation of Notary tasks and several other public services. Regarding the demand for notary role in electronic transactions, based on market needs, it is also based on global agreement in the United Nations Commission on International Trade Law (UNCITRAL) forum, which provides recommendations on the need for recognition of the legal value of electronic information and / or documents. ${ }^{2}$ Some countries have also implemented electronic notary or cyber notary in their national legal system, especially in the context of the need for guaranteed authenticity of electronic information, to support the implementation of digital signatures.

Notaries as officials or professionals in the field of law who have been sworn to act in accordance with the rule of law, are needed to ensure the legality of legal certainty

\footnotetext{
${ }^{1}$ Lecturers Of Faculty Of Law, UNISSULA, Semarang email: masrurridwan4@gmail.com

2 Huala Adolf, 2005, Hukum Perdagangan Internasional, Edisi 1, Jakarta: RajaGrafindoPersada, p. 168
} 
and prevent unlawful acts. The application of online media in all lines of people's lives at this time, in addition to ease, apparently also leaves a problem. The position of notary in real life, especially in daily transaction activities, has been recognized and respected as a legal position trusted by the community. The notary mixes the theory and practice of law in an ideal level, both in line or not (between theory and practice). In a sense, not always the existing legal theories always support the practice of notaries in the field. In this case, the "notary world" must continue to be built and developed, not only through existing legal theories, but must also be able to develop supporting theories themselves. the implementation of the duties of notary office based on their experience while carrying out the office of a notary public.

Law No. 2 of 2014 concerning the Position of Notary (UUJN), has confirmed that the Notary has an important role and function in transaction legality in Indonesia. Notary is also considered as a trusted third party. Notary services are the real answer to the legal needs of the community, not only in making the deed, but also as a witness or mediator of the transactions made by the public. The function of a notary public is based on the reality of the needs and desires of the community itself. Notary is not possible to do this type of work or make a deed without request from the customer.

When the communication media and information technology that is in the midst of society increasingly advanced and continues to grow, the notary must also be ready to welcome that era. The concept of cyber notary or cyber notary is a form of answer to the challenges of the development of information technology which has now globalized. This can be seen from the rapid development of information technologybased transactions by utilizing online applications, and similar-based public services.

Although the notary has worked hard to balance the market needs (the community), the UUJN has not explicitly regulated the authority of a notary in making a notarial deed electronically. Article 1 number 7 UUJN only states: "Notary Deed, hereinafter referred to as Deed, is an authentic deed drawn up by or before a Notary according to the form and procedure stipulated in this Law". The editorial of Article 1 number 7 of the UUJN provides an understanding that a notarial deed must be made before a notary public; and the parties must face the notary. Judging from the notarial notary deed above, there is no other interpretation, other than that the opportunity to make a notarial deed by utilizing the development of online technology is very small. This is in accordance with UUJN which requires that the deed be made before a notary public.

\section{Methods And Materials}

The study used in this paper uses normative juridical studies with a statutory and conceptual approach. The legislative approach is used to analyze various regulations related to the implementation of cyber notary, and the conceptual approach used to analyze and study comprehensively about the concept of cyber notary. ${ }^{3}$ The existing rules so far are considered to no longer meet the expectations of the community, because it needs to be reconstructed, in order to be able to answer the needs and

${ }^{3}$ H. Salim HS dan Erlies Septiana Nurbani, 2013, Penerapan Teori Hukum Pada Penelitian Tesis dan Disertasi, Jakarta: Rajawali Pers, p. 17. 
Volume 7 Issue 1, March 2020

Nationally Accredited Journal,

Decree No. B/4130/E5/E5.2.1/2019

desires of the people who continue to develop along with advances in information technology.

\section{Discussion}

\subsection{Making Deed Online}

Making a notary deed online (in the network) turned out not only to provide benefits, but also to bring up some problems. The advantages of making a notary deed online include time and cost efficiency. But on the other hand, the use of online technology also raises several problems related to the law. The rapid development of society is still inversely proportional to the development of law in Indonesia which is always lagging behind. There are many legal arrangements in Indonesia, but both in terms of material and substance have not been able to keep up with the development of the current digital era.

According to Rini Irianti Sundary ${ }^{4}$, problems that arose after the making of authentic deeds online include those related to notary obligations to the deeds he made, as regulated in Article 16 paragraph (1) of the UUJN, specifically letters c, and m, which read in full: 1. Attaching letters and documents and fingerprints to the Minutes of Deed. 2. Read out the Deed before the parties, attended by at least 2 (two) witnesses, or 4 (four) special witnesses for the making of a will, and signed at the same time by the parties, witnesses, and Notaries.

Based on the two forms of deed made by notaries, it is currently not possible to apply online technology in making electronic notary deeds; Especially in making a voluntary deed, at where the presence of a notary public in front of the parties is a necessity, so that an official report can be made containing the notary description seen and witnessed by the notary himself at the request of the parties.

Besides Law No. 11/2008 which was later amended by Law No. 11/2016 on Information and Electronic Transactions (ITE) Article 5 paragraph (4) letters $a$ and $b$ have confirmed that documents made in the form of notarial deeds are not included in electronic information and / or electronic documents. Thus the notary deed made electronically does not obtain legal force as valid evidence according to the provisions of the ITE Law. Limitation of the meaning of electronic information / electronic documents regulated in Article 5 paragraph (4) letters a and b, automatically makes an authentic deed made electronically by a notary deemed not to be valid evidence. Thus, the authenticity of the deed made by a notary in that case is not fulfilled.

From this brief description, it can be understood that the legal substance in making notary deeds online (electronically) has not been fully accommodated, both in the regulation of UUJN and in the ITE Law. Whereas both of these laws are the legal basis for notaries in capturing opportunities to make deeds online (electronically) in

\footnotetext{
${ }^{4}$ HarianKompas, Jumat, 20 April 2018 p. 33
} 
accordance with the demands and developments of modern society that are happening right now.

Actually, if we look closely, even though the regulations on UUJN, the Civil Code and the ITE Law, have not yet made it possible to make a deed online by a notary, the opportunity to make a deed online remains open by regulating the making of an electronic deed. It's just that in its implementation it cannot be applied, given the legal constraints that are still faced by notaries. However, the provisions of Article 77 of Law No. 40 of 2007 concerning Limited Liability Companies (UUPT) can be a legal gesture that shows an opportunity for a notary to make a deed online. It's just that this provision is not in sync with the substance of the ITE Law that appeared later. In the ITE Law, the authority of a notary in making an electronic deed is actually limited; while the need for short and fast services has become a necessity that is needed in the midst of modern society. That need was increasingly felt in the era of the COVID-19 pandemic which forced all parties to remain at home. More than tha the development of online technology is now more advanced; all parties can still see and communicate directly with other parties, as if like face to face.

\subsection{Basic Concepts of Cyber Notary}

The term and concept of cyber notary in Indonesia first appeared in Law Number 2 of 2014 concerning Amendment to Law Number 30 of 2004 concerning Notary Position (UUJN) which mentions several Notary authorities, as stated in article 15 of the 2014 UUJN. Article 15 paragraph (3) UUJN raised the phrase "... other authorities regulated in statutory regulations". Explanation of what is meant by "other authority", as clearly stated in the explanation of Article 15 paragraph (3), which reads: "What is meant by" other authorities regulated in statutory regulations ", among other things, the authority to certify transactions carried out electronically (cyber notary), making a Deed pledge deed, and aircraft mortgages. " Even so UUJN still does not mention the normative definition of cyber notary. Because of that the concept of cyber notary can refer to the understanding put forward by experts.

According to R.A. Emma Nurita, "The concept of cyber notary for a while can be interpreted as a notary who carries out the duties and authorities of his position based on information technology related to the duties and functions of the notary, especially in making the deed." ${ }^{5}$ Edmon Makarim believes that the concept of cyber notary in Indonesia is still under debate. Even though the available technology has made it possible for Notaries to play online and remote, legally, it seems that it cannot be done. ${ }^{6}$ Referring to the two opinions at the level, it is seen that both have similarities, namely, the notary uses the cyberspace media, which is related to the duties and authorities in carrying out his position.

\footnotetext{
5 Nurita, R. A. Emma. 2012. CYBER NOTARY (Pemahaman Awal),Bandung: Refika Aditama, p. 4

6 Edmon Makarim, "Modernisasi Hukum Notaris Masa Depan: Kajian Hukum Terhadap Kemungkinan ..". Jurnal Hukum dan Pembangunan. Vol. 41, No. 3 (2011), hlm. 287, diakses pada 7 Mei 2020.. Sumber. doi: http:// dx.doi.org/10.21143/jhp.vol41.no3.287
} 
Volume 7 Issue 1, March 2020

Nationally Accredited Journal,

Decree No. B/4130/E5/E5.2.1/2019

The concept of cyber notary itself is not regulated in the order of definitions or arrangements or the mechanism of its implementation. But Cyndiarnis Cahyaning Putri and Abdul Rachmad Budiono gave a limitative interpretation of cyber notary with give the meaning of "authority for certification of transactions carried out electronically"7 With this interpretation both of them argue, that the authority applies limitatively to only one authority, namely with regard to the certification of electronic transactions.

Based on the Legal Certainty Theory, both provide the meaning of the Notary's authority over cyber notaries that were initially unknown whether the act may or may not be carried out due to a legal vacuum (rechtsvacuum), the limitations being clear, which is limited to apply to the certification of electronic transactions.

Both of them also argue that along with the development and advancement of information technology, the opportunity for the application of Cyber Notary in the Legal System in Indonesia has a probability of its authority to make a deed. This can be assessed from the existence of Law Number 40 Year 2007 regarding Limited Liability Companies (UUPT) which gives the possibility to conduct a General Meeting of Shareholders (GMS) remotely. Although they agree that in the near future cyber notary can be carried out in Indonesia, but the author disagrees with making UUPT as a reference. However the UUPT of legal products in 2007, while UUITE came later, namely in 2008. That means the UUITE who came more back has a stronger position than the UUPT.

Opportunities for applying the concept of cyber notary, although not in the perspective of deed making, can be reviewed through the storage of the Notary protocol. Indah Kusuma Dewi said that the opportunity for electronic Notary protocol storage to be carried out was possible. That is because the Notary has implemented an electronic application in accordance with the Regulation of the Minister of Law and Human Rights of the Republic of Indonesia Number 4 of 2014 concerning Procedures for Filing Requests for Legal Entity Approval and Approval of Amendments to the Articles of Association and Submission of Notification of Amendments to Articles of Association and Amendments to Limited Company Data; Minister of Law and Human Rights Regulation No. 5 of 2014 concerning Ratification of Foundation Legal Entities; and Ministerial Regulations Law and Human Rights of the Republic of Indonesia No. 6 of 2014 on the ratification of the Law Society, although the transfer of electronic data storage only serves as a back up, not as a binding legal force.

Thus, normatively, the opportunities for the creation of the UUPT General Shareholders' Meeting Act and electronic Notary protocol storage have opened up to the possibility of making the deed by taking advantage of technological developments. The problem is that there is a Notary obligation in the making of an act, as set forth in Article 16 paragraph (1) of the letter $\mathrm{m}$ stating that the Notary is obliged to "read the

7 Cyndiarnis Cahyaning Putri dan Abdul Rachmad Budiono, Konseptualisme dan peluang cyber notary dalam Hukum, Jurnal Ilmiah Pendidikan Pancasila dan Kewarganegaraan, Volume 4, Nomor 1, Halaman 29-36 ISSN: 2528-0767 (p) dan 2527-8495 (e) http://journal2.um.ac.id/index.php/jppk 
Act before the audience attended by at least 2 (two) witnesses, or 4 (four) special witnesses to the making of a will under the hand of the will, and signed at that time by witnesses, witnesses and notaries. ".

The clarification of the article also emphasized that the Notary should be physically present and sign the Act in the presence of witnesses and witnesses. It is this "physical" phrase that drives the concept of cyber notary or the making of an act by exploiting the development of information technology.

Authoritarianism, the striking contradiction between the notarial obligation and authority, which ultimately led to the clash of norms was created before information technology developed today, allowing parties, witnesses and Notaries to "see / see and see each other" with one another. the other party. Therefore, the sense of presence or physical presence needs to be adapted to the advancement and development of modern information technology. Especially in the current COVI-19 pandemic, where work from home is enforced, and some meetings or meetings take place using the Zoom application facility or google meet. Just because the Notary is still barred by Article 16 paragraph (1) of the letter $m$, which imposes an obligation to be physically present, then that obligation automatically eliminates the essential elements of the notary cyber concept itself. If the Notary does not perform the obligations as referred to in Article 16 paragraph (1) of the letter m, then the power of proving the Notary Act will be degraded into an act under his hand. This is in accordance with the provisions Article 16 paragraph (9) which reads: "If one of the conditions referred to in paragraph (1) letter $\mathrm{m}$ and paragraph (7) is not fulfilled, the Deed concerned only has the power of proof as a deed under the hand." Thus, it is very clear that although UUJN has presented the concept of cyber notary within the authority of a Notary Public, it has not yet provided an opportunity for the application of the concept of cyber notary.

\subsection{Reconstruction of Notary Position Authority}

From a brief review of the possibility of the implementation of cyber notary in Indonesia as described above, it can be stated that in order to have legal certainty and legal benefits for the community, it is necessary to reconstruct the legal rules related to the authority of Notary Public, as desired by the basic concept of cyber notary. The expansion of authority is not just to provide flexibility to the notary in making notarial deeds, but primarily to meet the interests of the general public Notary services users who want to get fast, cheap services and notarial deeds have legal force in line with conventional notarial deeds.

Some of the articles that need to be reconstructed are the articles in the legislation relating to the authority to make a notarial deed by a notary made online. Some articles that need to be reconstructed include:

- Article 16 paragraph (1) UUJN, specifically letters c, and m, which reads in full: 1. Attaches letters and documents and fingerprints to the Minutes of Deed. 2. Read out the Deed before the parties, attended by at least 2 (two) witnesses, or 4 (four) special witnesses for the making of a will, and signed at the same time by the parties, witnesses, and Notaries. The article needs to be reconstructed, adjusting to 
Volume 7 Issue 1, March 2020

Nationally Accredited Journal,

Decree No. B/4130/E5/E5.2.1/2019

the online era, adapted to the needs of the community and the development of the times.

- Article 5 paragraph (4) letters a and b of Law No. 11/2008 which is then amended by Law No. 11/2016 concerning Electronic Information and Transactions (ITE). Article 5 paragraph (4) letters a and $b$ have confirmed that documents made in the form of notarial deeds are not included in electronic information and / or electronic documents. This article limits the making of notary deeds that are made electronically not obtaining legal force as valid evidence according to the provisions of the ITE Law. Limitation of the meaning of electronic information / electronic documents regulated in Article 5 paragraph (4) letters $a$ and b, automatically makes an authentic deed made electronically by a notary deemed not to be valid evidence. Thus, the authenticity of the deed made by a notary in that case is not fulfilled.

The article also needs to be reconstructed, adjusting to the online era, adapted to the needs of the community and the development of times.

In addition to reconstructing the articles which obstruct the implementation of cyber notary, it is also necessary to act in harmony with the laws and regulations related to the notary's authority in making electronic deeds. namely between UUJN and ITE Law and between the UUPT and UUJN. By reconstructing and harmonizing regulations, it is hoped that notaries will no longer experience juridical problems regarding their authority in making electronic deeds, and the public will no longer be hesitant with regard to the various electronic transactions they carry out.

\section{Conclusion}

The implementation of cyber notary which has become a necessity as a form of adjustment to the needs of the community and the development of the times, although its presence is agreed to be impossible to avoid, but it still cannot be carried out in Indonesia. Some existing laws and regulations do not allow the implementation of the cyber notary work system, even though the Notary as a professional practitioner in the field of law is ready to carry out. The current implementation of cyber notary will actually reduce the strength of proof of authentic deed. Therefore, several articles in several laws and regulations which need to be reconstructed must be immediately reconstructed, as well as synchronized. The era of the COVID-19 pandemic which "requires" everyone to work from home can be a momentum for action in that direction. Articles that need to be reconstructed and synchronized include the sound of the phrase Article 5 paragraph (4) of the ITE Law and the phrases in Article 16 paragraph (1) of the UUJN, specifically letters c, and m.

\section{References}

[1] Abdul Halim Barkatullah, 2017, Hukum Transaksi Elektronik di Indonesia, Bandung: Nusa Media. 
eISSN : 2581-2114, pISSN: 2406-9426

[2] H. Salim HS dan Erlies Septiana Nurbani, 2013, Penerapan Teori Hukum Pada Penelitian Tesis dan Disertasi, Jakarta: Rajawali Pers.

[3] Huala Adolf, 2005,Hukum Perdagangan Internasional, Jakarta: RajaGrafindo Persada.

[4] Nurita, R. A. Emma. 2012. CYBER NOTARY (Pemahaman Awal),Bandung: Refika Aditama.

[5] Edmon Makarim, "Modernisasi Hukum Notaris Masa Depan: Kajian Hukum Terhadap Kemungkinan ..". Jurnal Hukum dan Pembangunan. Vol. 41, No. 3 (2011), hlm. 287, diakses pada 7 Mei 2020.. Sumber. doi: http:// dx.doi.org/10.21143/jhp.vol41.no3.287

[6] Cyndiarnis Cahyaning Putri dan Abdul Rachmad Budiono,Konseptualisme dan peluang cyber notary dalam Hukum, Jurnal IImiah Pendidikan Pancasila dan Kewarganegaraan, Volume 4, Nomor 1, Halaman 29-36 ISSN: 2528-0767 (p) dan 2527-8495 (e) http://journal2.um.ac.id/index.php/jppk

[7] Kitab Undang-Undang Hukum Perdata, 2018, Cetakan I, Yogyakarta: Solusi Distribusi.

[8] UU No. 40 Tahun 2007 tentang Perseroan Terbatas. LNRI Tahun 2007 Nomor 106.. TLN Nomor 4756.

[9] UU No. 11 Tahun 2008 tentang Informasi dan Transaksi Elektronik. LNRI Tahun 2008 Nomor 58. TLN Nomor 4843.

[10] UU Nomor No. 30 Tahun 2004 tentang Jabatan Notaris. LNRI Tahun 2004 Nomor 117. TLN No. 4432.

[11] UUU Nomor 2 Tahun 2014 tentang Perbahan Atas Undang-Undang Nomor 30 Tahun 2004 tentang Notaris. LNRI Tahun 2014 Nomor 3. TLN Nomor 5491.

[12] UU No. 19 Tahun 2016 tentang Perubahan Atas Undang-ndang Nomor 11 Tahun 2008 tentang Informasi dan Transaksi Elektronik. LNRI Tahun 2016 Nomor 251. TLN Nomor 5952

[13] Harian Kompas, Jumat, 20 April 2018. 